\title{
Strong seasonal effects of waterbirds on benthic communities in shallow lakes
}

\author{
Héctor Rodríguez-Pérez ${ }^{1}$ AND Andy J. Green ${ }^{2}$ \\ DepartmentofWetland Ecology, Estacio 'nBiolo'gicadeDon ana(CSIC).C/Ame 'ricoVespucios/n, \\ 41092 Sevilla, Spain
}

\begin{abstract}
Little is known about the effects of waterbirds on benthic macroinvertebrates in nontidal habitats. We conducted 4 waterbird-exclusion experiments in a transformed marshland in Doñana Natural Park (southwestern Spain) and compared benthic macroinvertebrates in $3 \times 3$-m control (no exclusion) and test plots from which Greater Flamingos Phoenicopterus ruber or all waterbirds were excluded. The 4 experimental periods coincided with the waterbird breeding season (summer), postbreeding period (autumn), wintering period (winter), and pre- and early breeding season (spring). Densities of waterbirds were relatively low compared to densities reported in other studies, but we found strong effects of excluding flamingos and waterfowl on the structure of the benthic community in autumn, winter, and spring. In winter, numbers of polychaetes and chironomids were nearly $2 \times$ higher in exclusion than in control plots. The difference in macroinvertebrate biomass among treatments was strongest in winter when benthic dry mass was $\sim 2 \times$ higher in flamingo exclosures than in control plots and $\sim 2 \times$ higher in all-bird exclosures than in flamingo exclosures. Macroinvertebrate richness was $15 \%$ lower in control than in allbird exclosures in winter and 25\% lower in control than in all-bird exclosures in spring. Our results suggest that benthic macroinvertebrate communities in this wetland are affected more by predation, bioturbation, and waterbird herbivory than by competition. These findings suggest that waterfowl and the increasing population of flamingos are of great importance in structuring shallow lakes in the Mediterranean region.
\end{abstract}

Key words: exclosures, benthic community, top-down effects, waterbirds, flamingos, Phoenicopterus ruber, predation, bioturbation.

Competition, predation, and disturbance (biotic and abiotic) are 3 major forces driving the structure of animal communities, but their relative strength depends on habitat type, environmental stress, and vital rates (Roughgarden and Diamond 1986, Menge and Sutherland 1987). In aquatic systems, many paradigms for community ecology have been established using intertidal rocky zones as a model system (Paine 1966, 1980, Lubchenco and Menge 1978, Sousa 1979, Menge et al. 1994, Berlow 1997). The relative importance of biological processes in structuring benthic communities appears to be less important in soft sediment than in the rocky intertidal zone because interspecific competition is weaker in this 3-dimensional habitat (Sih et al. 1985, Wilson 1991, Olafsson et al. 1994). Competition for resources is often the main determinant of community structure in other environments, but predation seems to be the

\footnotetext{
${ }^{1}$ Present address: Station Biologique Tour du Valat, Le Sambuc, 13200 Arles, France. E-mail: hector.hrp@gmail.com

2 E-mail address: ajgreen@ebd.csic.es
}

strongest determinant in soft-sediment communities (Peterson 1979, Wilson 1991, Olafsson et al. 1994, Thrush 1999, Sánchez et al. 2006). However, most studies of predation in soft sediments have been focused on invertebrate predators. Predation usually is studied via exclosure experiments (Sih et al. 1985). This experimental approach has its complications (Rosa et al. 2008), largely solved by correct replication (Hurlbert 1984) and the use of control plots.

Waterbirds are important benthic predators in marine and inland aquatic systems. Authors of various exclosure studies have focused on the role of shorebirds as predators on benthic invertebrates in the intertidal zone (Quammen 1984, Botto et al. 1998, Mendoça et al. 2007, Rosa et al. 2008), but studies of other bird groups or in other habitats are infrequent. Ducks feed on benthic invertebrates (Kear 2005), and diving ducks have profound effects on the abundance of bivalves (Hamilton et al. 1994, Hamilton 2000, Mitchell et al. 2000, Yamamuro et al. 1998). However, few studies have been done on the influence of waterfowl (i.e., Anatidae and coots) on other benthic 


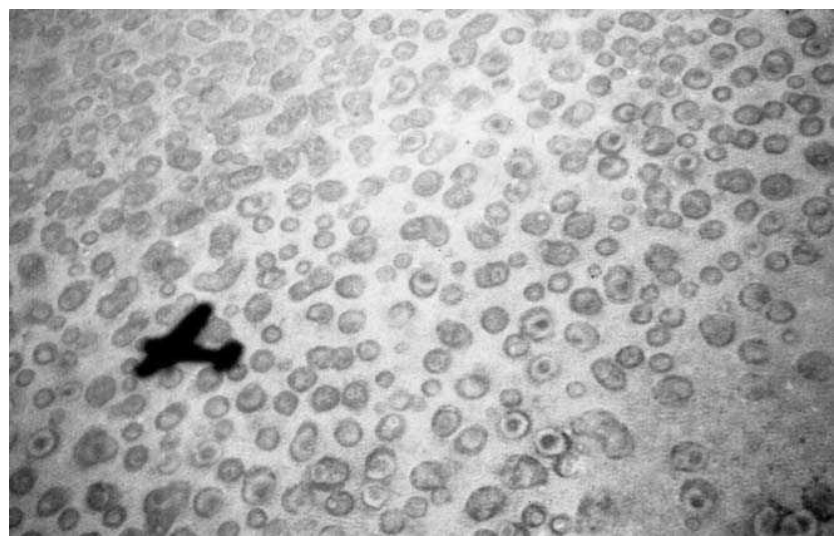

FIG. 1. Aerial photograph of craters (diameter 1-1.5 m) made by Greater Flamingos in the ponds in Veta la Palma. The flamingos were flushed immediately before the photograph was taken. Author Héctor Garrido/Equipo de Seguimiento de Procesos Naturales.

invertebrates (Smith et al. 1986, Bortolus et al. 1998, Marklund and Sandsten 2002). In contrast, the role of waterfowl as herbivores has been investigated repeatedly with exclosure experiments (e.g., Mitchell and Perrow 1998, Gayet et al. 2011).

In exclosure experiments, flamingos (Phoenicopteridae) significantly affect benthic organisms (Hurlbert and Chang 1983, Glassom and Branch 1997a, b) and macrophytes (Rodríguez-Pérez and Green 2006). The effects of flamingos appear to be caused directly by predation and indirectly by bioturbation produced by their feeding behavior (Fig. 1). Since 1970, populations of Greater Flamingos (Phoenicopterusruber) have increased dramatically in size in the Mediterranean region, and they are now one of the most abundant waterbirds in terms of biomass (Johnson 1997, Wetlands International 2006, Rendón et al. 2008).

The main objectives of our work were to estimate the effect of waterbird predation on the benthic community at times of the year with seasonal differences in invertebrate and bird abundance and to compare the importance of flamingos and other waterbirds. We excluded separately Greater Flamingos and waterfowl in shallow brackish marshes in southwestern Spain during four 3-mo periods of the annual cycle. We considered the effects of the 2 waterbird groups on invertebrate abundance and on community traits, such as taxonomic richness and total dry mass. We showed that predation by waterbirds is a major force structuring the benthic community and consider the effects of seasonal changes in bird and invertebrate abundance.

Ours is a novel study that addressed simultaneously the effects of 2 functionally (sensu Duffy 2002) different groups of waterbirds on a nontidal benthic community (but see Marklund and Sandsten 2002) and compared the effects at different times during the annual cycle (see Hamilton 2000 for such a study in an intertidal community).

\section{Methods}

\section{Studyarea}

We carried out exclosure experiments in Veta la Palma (VLP; lat $36^{\circ} 57^{\prime} \mathrm{N}$, long $6^{\circ} 14^{\prime} \mathrm{W}$ ), a private fish farm divided into 52 regular ponds within Doñana Natural Park. The ponds were constructed in 1992 1993 on top of what was natural marshland in the Guadalquivir estuary (Fig. 2). This habitat has some similarities with marine soft sediments and is supplied with estuarine water. All the ponds are shallow (mean depth $=30 \mathrm{~cm}$, maximum depth $=50 \mathrm{~cm}$ ) and flat-bottomed with a total combined surface area of 2997 ha. The species cultured are European seabass (Dicentrarchuslabrax), flathead mullet (Mugilcephalus ), gilthead seabream (Sparus auratus), eels (Anguilla anguilla), and Atlantic ditch shrimp (Palaemonetes varians). Each pond is dried out under rotation approximately every 2 y to extract fish. Ponds are interconnected via canals, and permanent flow of water taken from the Guadalquivir estuary maintains dissolved $\mathrm{O}_{2}$ levels (see Frisch et al. 2006, Kloskowski et al. 2009 for details).

The dominant submerged macrophyte species is Ruppiamaritima, which forms extensive beds during spring and early summer. Small patches of Potamogeton pectinatus occur in some ponds in years of relatively low salinity. Most of the shoreline is bare mud, and regular dredging done to prevent siltation of peripheral canals used to extract fish from the ponds has restricted development of vegetation, which is dominated by Arthrocnemum macrostachyum and Suaeda spp. with patches of Phragmites australis and Scirpusmaritimus . Mean monthly air temperature during the study varied from $11.8^{\circ} \mathrm{C}$ in February to $23.5^{\circ} \mathrm{C}$ in July. Mean annual precipitation is $562 \mathrm{~mm}$ with a range of 158 to $1062 \mathrm{~mm}$ (Castroviejo 1993). Salinity in the ponds during our study varied from $7 \mathrm{~g} / \mathrm{L}$ during winter months of high rainfall to $15 \mathrm{~g} / \mathrm{L}$ at the end of September, after the dry summer months typical of the Mediterranean region. $\mathrm{pH}$ ranged from 9.3 to 10.4 .

\section{Experimentaldesign}

Aerial surveys of waterbirds in VLP were done monthly during the study as part of a regular monitoring program carried out by the Doñana 


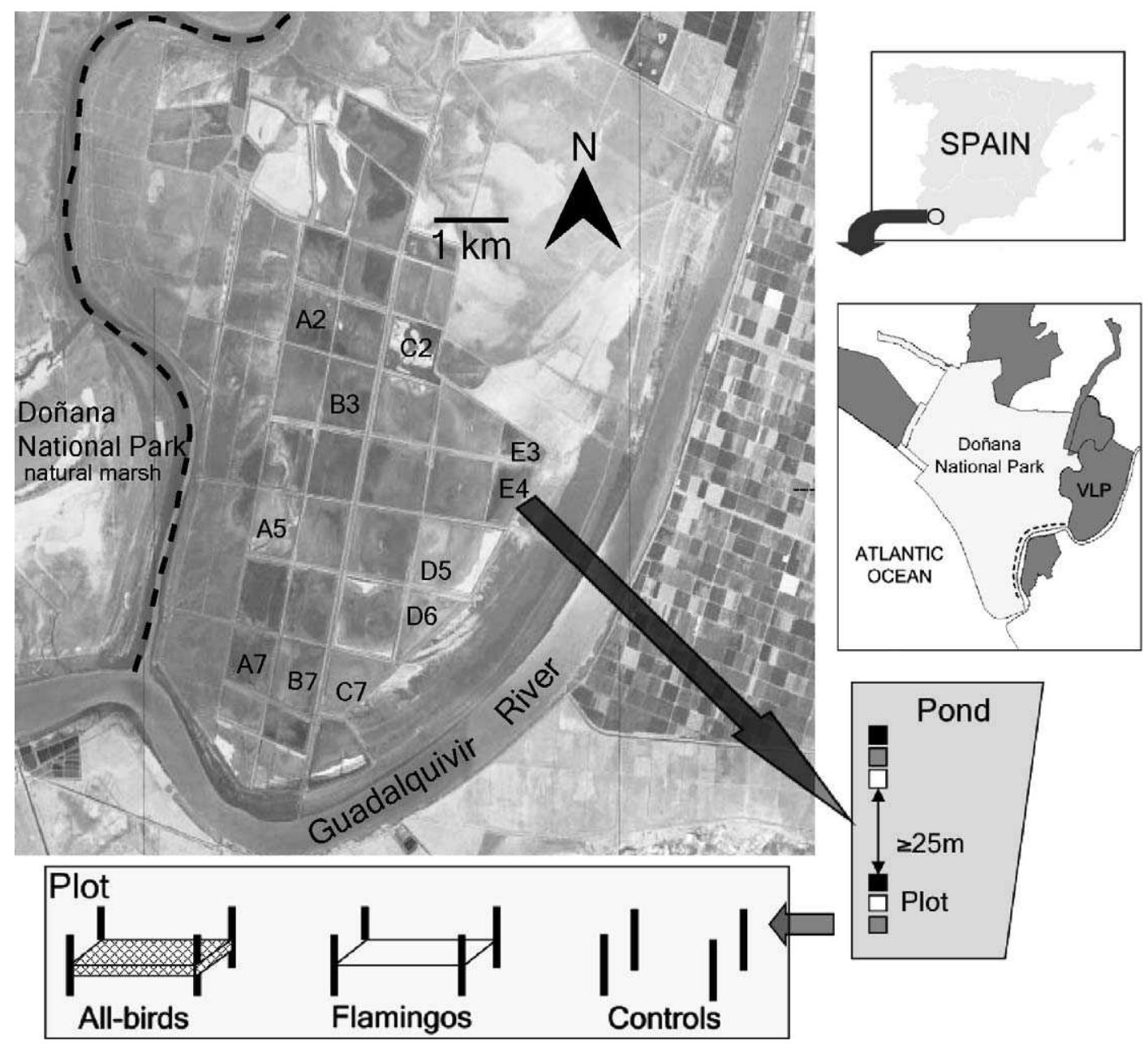

FIG. 2. Map of the study area showing its location within the Iberian Peninsula. Ponds used in the study are labeled with their local names. A schematic drawing shows an example of the position of experimental blocks and of the different treatments within each block. Image source: Digital Orthophotography of Andalusia (1998-1999) Projection UTM Datum European 1950, Spain and Portugal Zone 30.

Biological Station to census birds of the Doñana National and Natural Parks and surrounding areas (http:/ / wwwrbd.ebd.csic. es / Seguimiento / mediobiologico.htm). All birds were counted, including those on the water and in flight (most of which were flushed by the plane). Densities were calculated based on the total VLP pond area of 2997 ha. Flamingos are consistently recorded at higher density in VLP than in surrounding areas, whereas the numbers of ducks and coot are strongly influenced by the variable flooding pattern of adjacent temporary marshes (Rendón et al. 2008, Kloskowski et al. 2009, Almaraz et al. 2012).

We used 8 ponds for experimental periods of 3 mo. Three ponds were substituted when they were drained to extract fish, making a combined total of 11 different ponds used during the 4 experimental periods (range 26-114 ha, making a total of $697 \mathrm{ha}$ ). We included ponds that had been flooded for different lengths of time when we started the experiment.

We used 2 exclosure and 1 control (C) treatments. All exclosures and controls were $3 \times 3 \mathrm{~m}$. The all-birds $(\mathrm{A})$ treatment consisted of 2-cm-mesh nylon netting tied to a square polyvinyl chloride (PVC) frame suspended from 4 iron poles ( $2 \mathrm{~m}$ long, $10 \mathrm{~mm}$ diameter) pushed into the pond bottom in each corner. We attached wires from the tops of the poles to the center of the net to prevent it from touching the water surface. At the sides of the square frame, $20 \mathrm{~cm}$ of netting hung vertically down to the water surface to prevent birds from passing underneath. This design allowed fish to enter but prevented entry by ducks, coots, and other birds. The netting did not visibly affect water movement. No algal growth occurred, and shading was $<3 \%$ because of the large mesh size. 
The flamingo-only (F) treatment excluded only flamingos. We placed 4 iron poles in each corner of the square as before and tied a 2-mm-diameter wire around them at a height of $70-$ to- $75 \mathrm{~cm}$ from the bottom (30-65 $\mathrm{cm}$ above the water surface). We selected this height after field trials confirmed that flamingos did not enter the exclosures but other birds passed comfortably under the wire and freely entered the exclosures. Controls consisted merely of the 4 iron poles. We frequently observed Eurasian Coots Fulica atra and ducks feeding inside controls and flamingo exclosures, whereas we never observed birds inside all-bird exclosures. We made no attempt to quantify the use of control plots and flamingo exclosures in detail. Black-tailed Godwit Limosa limosa and other larger shorebirds probably entered the shallowest plots occasionally.

We used a randomized complete block design in which each experimental block contained one exclosure of each kind and a control, randomly placed and separated by $\sim 10 \mathrm{~m}$ (Fig. 2). We placed 2 experimental blocks separated by $\sim 25 \mathrm{~m}$ in the western part of each pond. We aligned all exclosures and controls at an equal distance from the pond edge to expose them equally to the dominant southwesterly wind with an equal and relatively low fetch. We ran four 3-mo experiments between April 2001 and June 2002, and we moved the exclosures and controls $10 \mathrm{~m}$ toward the centers of the ponds at the beginning of each new experiment. Depth did not change toward the centers of the ponds. The ponds lacked a significant fringe of emergent vegetation and constant depth, so no windbreak existed along the pond edge and no gradient in waterbird density from the edge to the center of the ponds could have influenced waterbird effects as we moved controls and exclosures between experimental periods (Weisner et al. 1997).

We used this experimental design with short-term exclusion to test the consequences of seasonal shifts in the populations of both waterbirds and invertebrates by dealing with each season separately. A long-term design with repeated sampling of fixed plots over a whole year would have enabled us to test for cumulative effects of bird exclusion on invertebrate populations, but we could not have identified the effects of waterbirds in a given season. The first experimental period was from 3 April to 11 July 2001 (Jul01), coinciding with the breeding period for waterbirds. Installation of experimental exclosures was delayed $\sim 20 \mathrm{~d}$ in 2 ponds (D6 and E3) because of delays in acquisition of experimental materials. Thus, the experimental treatment ran for only 2 mo in these 2 ponds. The $2^{\text {nd }}$ period, from 13 July to 30 October 2001 (Oct01), corresponded with the post-breeding period. The $3^{\text {rd }}$ period, from 22 November 2001 to 27 February 2002 (Feb02), covered the wintering period. The $4^{\text {th }}$ period, from 7 March to 6 June 2002 (Jun02), overlapped with the prebreeding and early breeding periods. Each exclosure or control was set for 70 to 93 d in Jul01, 82 to 92 d in Oct01, 95 to 105 d in Feb02, and 88 to $96 \mathrm{~d}$ in Jun02. In a given pond and period, we established or sampled all exclosures and controls on the same day. Experimental periods overlapped slightly because we needed $\sim 2$ wk to sample and move exclosures and controls in the ponds, and bad weather caused some delays.

We collected 3 cores $\left(23.8 \mathrm{~cm}^{2}\right.$ surface area) in each $3 \times 3 \mathrm{~m}$ plot at the beginning and the end of each experimental period. We took initial cores just after the installation of exclosures $0.5 \mathrm{~m}$ from the edge at 3 different points in the plot. We took final cores from the central area $\geq 1 \mathrm{~m}$ from the edge to reduce edge effects and to avoid spots sampled at the beginning. Each core was separated by $\geq 1 \mathrm{~m}$ from all others. The water depth at sampling points ranged from 10 to $39 \mathrm{~cm}$ (mean $\pm \mathrm{SE}=27 \pm 8 \mathrm{~cm}$ ) and was within the range accessible to dabbling ducks when feeding (Pöysä 1983, Green 1998). We pooled the 3 cores to avoid pseudoreplication.

We extracted the upper $5 \mathrm{~cm}$ of sediments in each core with a PVC tube and fixed them with formalin. We passed each sample later through a $250-\mu \mathrm{m}-\mathrm{mesh}$ sieve, sorted invertebrates retained on the sieve into taxonomic groups, and counted them with the aid of a binocular microscope. We identified invertebrates to the lowest possible taxonomic level (species level in some cases) with the following keys and help from specialists (see Acknowledgements): Fauvel (1923, 1927), Argano (1979), Ghetti and McKenzie (1981), Castello (1986), Holthe (1986), Jansson (1986), Askew (1988), Ruffo (1982), Ortiz and Jimeno (2001), and Tachet et al. (2003). To quantify the dry mass of each sample, we dried invertebrates for $24 \mathrm{~h}$ at $80^{\circ} \mathrm{C}$ and weighed them to the nearest $0.0001 \mathrm{~g}$. When samples weighed less than the minimum measurable value $(0.0001 \mathrm{~g})$, we assumed a mass $1 / 2$ of this value (0.00005 g).

\section{Statisticalmethods}

Multivariate analyses of variance.- Invertebrate taxa can be expected to interact with mutual effects on their densities. Thus, data on different invertebrate groups from the same plot are not strictly independent. We used a collective multivariate analysis to test for treatment effects on overall community composition (the matrix of counts of each invertebrate group, including 0s). If a significant effect was confirmed, we 
analyzed the abundances of the most important invertebrate groups to establish which ones were driving the treatment effects.

We did not use repeated measures multivariate analysis of variance (MANOVA) or simple MANOVA to analyze community composition because many abundances were 0 and the data failed to meet assumptions that count data conform to a multivariate normal distribution, even after transformations. Instead, we used nonparametric multivariate analysis of variance (Anderson 2001) with the Adonis algorithm in the $\mathrm{R}$ package vegan 1.17-6 (Oksanen et al. 2011). We used Bray-Curtis dissimilarities on $\sqrt{ }(x)$ transformed abundances with 999 permutations to calculate $p$-values. We analyzed each period separately to avoid confounding spatial and temporal effects because we were forced to change some of the ponds included in the experiment. We did separate analyses for the data at the beginning and end of each experimental period to confirm that significant treatment effects at the end were caused by waterbird exclusion and not by initial differences.

The Adonis algorithm does not allow inclusion of random factors, but the calculation of pseudo- $F$ values for fixed factor (treatment) does not change regardless of whether the $2^{\text {nd }}$ factor (pond) is fixed or random because the variance-partitioning procedure follows the same model as in an analysis of variance (ANOVA) without replication with only 1 observation per cell (see Zar 1996 for ANOVA partitioning models). However, the Adonis algorithm handles nestedness properly to control the permutation procedure better. Furthermore, we were interested only in the significance of the treatment variable and not the differences in community composition among ponds. Thus, we correctly estimated the effect of treatment on community composition. Unfortunately, formal post hoc analysis cannot be done with the Adonis algorithm. To solve this problem, where the general analysis showed a significant treatment effect, we did pairwise comparisons by repeating nonparametric MANOVAs for 2 of the 3 treatments at a time and adjusting the level of $\alpha=0.05$ by Bonferroni correction.

We also ran nonmetric multidimensional scaling (NMDS) analysis of Bray-Curtis dissimilarities on $\sqrt{ }(x)$-transformed abundances.

Analyses with individual dependent variables. - We analyzed the effects of treatments (A, F, and C), experimental period, and their interaction on individual measures of invertebrate abundance or richness. We analyzed community richness (number of taxa/ sample), total dry mass/sample, and when we found a treatment effect on community composition, counts of individual taxa with Generalized Mixed Linear
Models (GLMs; McCullagh and Nelder 1989) with the GLIMMIX procedure (SAS, version 9.1; SAS Institute, Cary, North Carolina). We established a GLM for analysis of data with treatment as a fixed factor with 3 levels, pond, and experimental block nested within ponds as random factors. We considered all invertebrate groups recorded, including those not strictly benthic because the benthic-pelagic distinction functions as a continuum rather than a dichotomy in ponds (Vadeboncoeur et al. 2002).

We used an identity link and lognormal error distribution to analyze total dry mass per sample and richness, except for total dry mass for Jun01 for which data showed a normal error distribution. We used Tukey tests for post hoc analyses of least-squares means to identify significant differences among treatments. We usedF-statistics for tests on the effects of each predictor (Crawley 1993).

We used abundance and mass data for all taxa in models of total dry mass and taxon richness. We calculated taxon richness based on the finest taxonomic level we could reach and mixed species level with broader levels of identification. For example, corixids were dominated by the alien Trichocorixa verticalis (Rodríguez-Pérez et al. 2009), but we pooled all corixids because they were predominantly juveniles, which are not identifiable to species level.

We used a log-link function and negative binomial error distribution to analyze count data (Zuur et al. 2009). Models of taxa with low abundances and many 0 values did not converge. We analyzed counts for the 6 most abundant groups: polychaetes (dominated by Alkmaria romijni, Streblospio shrubsolii ), chironomid larvae (Chironomini tribe), the gastropod Potamopyrgus antipodarum, the ostracod Cyprideis torosa, the amphipodCorophiumorientale, and the isopodLekanesphaera hookeri. However, we present only those results with significant treatment effects and lacking problems with error distribution. Analyses with dry mass instead of counts produced similar results (not shown). We also recorded the following groups and species in low abundances: the polychaete Hediste diversicolor, the isopod Cyathuracarinata, the decapod shrimp Palaemonetes varians, water beetles (Berosus sp. and Enochrus sp.), corixids ( T. verticalis, Sigara stagnalis, and Sigarascripta), nymphs of the damselfly Ischnura graellsi, flatworms of the order Catenulida, and dipteran larvae Ephydra sp. We preferred not to add H.diversicolor data to those for other polychaetes because they are so different ecologically. Nereids are much larger and dig deeper burrows and were likely to be overlooked in our samples of $5 \mathrm{~cm}$ depth. Furthermore, unlike other polychaetes, they are predators (Verhoeven 1980, Smith et al. 1996). 

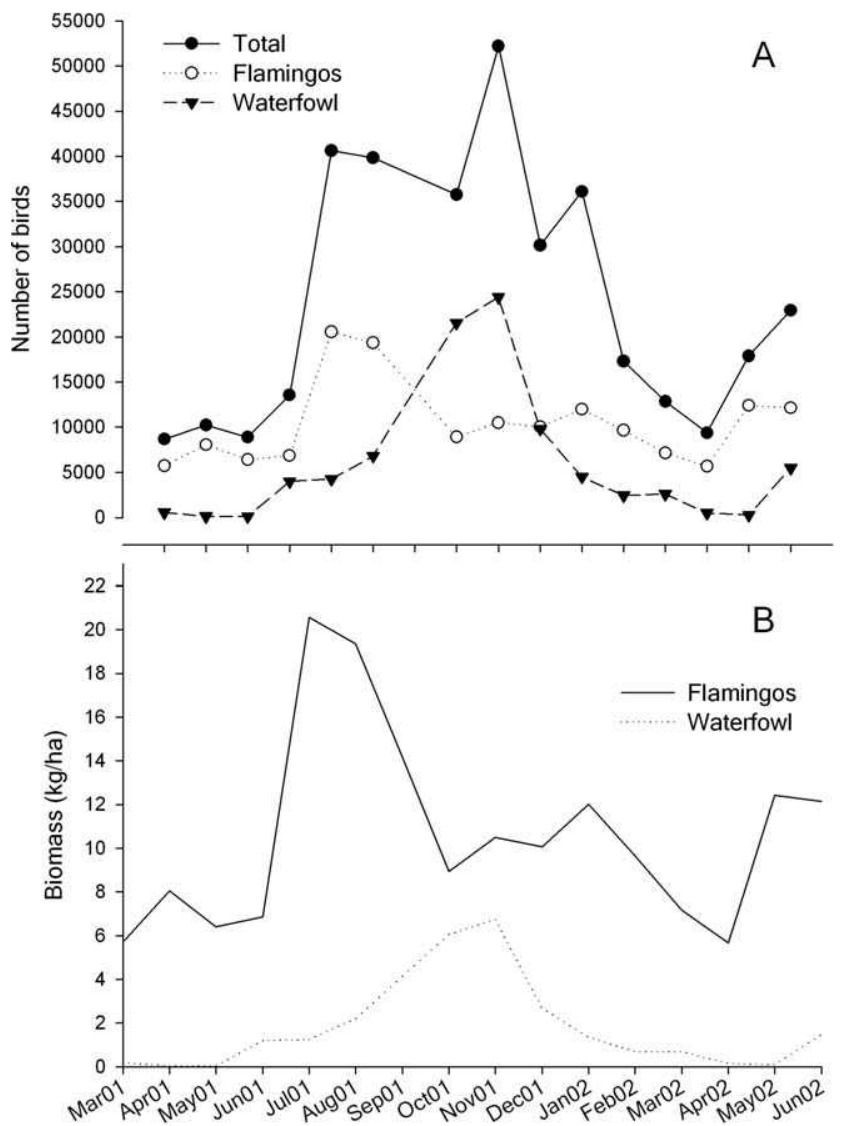

FIg. 3. A.-Aerial counts of waterbirds in Veta la Palma from March 2001 to June 2002. Totals represent all birds counted in the area, including shorebirds, gulls, etc. B.Biomass of flamingos and waterfowl during 4 experimental periods (Jul01 $=3$ April to 11 July 2001, Oct01 $=13$ July to 30 October 2001, Feb02 = 22 November 2001 to 27 February 2002, Jun02 = 7 March to 6 June 2002) in Veta la Palma. Calculations were based on body masses in del Hoyo et al. (1992).

We present figures of invertebrate abundance using geometric mean and geometric standard deviations to correspond with our use of the log-link function. To calculate these magnitudes, we added a constant (1) to every datum.

\section{Results}

\section{Waterbirdcounts}

Peak numbers of waterbirds occurred during the post-breeding period and reached $>50,000$ in November 2001 (Fig. 3A). Numbers remained high in midwinter and were lowest in March and April (Fig. 3A). Numbers of the largely herbivorous coots and ducks followed a similar pattern, peaking in October to November during the post-breeding period. Numbers of flamingos peaked in July to August at the height of their breeding season (Fig. 3A). In terms of biomass, flamingos were easily the most important birds in the area (Fig. 3B). Mean density of ducks and coot in Veta la Palma was 2.6 individuals (ind)/ha. Mean density of flamingos was 3.9 ind/ha. The most abundant waterfowl species recorded (in order of decreasing abundance) were Fulica atra, Anas platyrhynchos, Anas clypeata, Anas penelope, Anas acuta , Anas strepera ,Netta rufina, and Aythya ferina. The dabbling ducks (Anas spp.) accounted for $96 \%$ of the total number of ducks counted. Anas penelope, A. clypeata, and A. acuta were present only in winter.

\section{Measuresofbenthiccommunitystructureandcomposition}

Exclosure treatment did not affect initial community composition in any experimental period (Jul01: pseudo- $F_{2,38}=0.71, p=0.62$; Oct01: pseudo- $F_{2,38}=$ $1.29, p=0.23$; Feb02: pseudo- $F_{2,38}=1.37, p=0.21$; Jun02 pseudo- $F_{2,38}=0.54, p=0.81$ ). In contrast, exclosure treatment significantly affected final community composition in Oct01, Feb02, and Jun02 (Oct01: pseudo- $F_{2,38}=6.89, p=0.001 ;$ Feb02 pseudo- $F_{2,38}=6.48, p=0.001$; Jun02 pseudo- $F_{2,38}=$ $4.82, p=0.002$ ), but not in Jul01 (pseudo- $F_{2,38}=0.74$, $p=0.69$ ).

We did pairwise post hoc comparisons for the 3 periods with significant results (9 tests, adjusted $\alpha=$ 0.0055). In Oct01, $C$ differed from $A$ and $F$ exclosures ( $\mathrm{C}$ vs F: pseudo- $F_{1,23}=6.88, p=0.002 ; \mathrm{C}$ vs $\mathrm{A}$ : pseudo- $F_{2,38}=11.38, p=0.001 ; \mathrm{F}$ vs A: pseudo- $F_{2,38}=$ $2.31, p=0.08$ [all $p$-values before Bonferroni correction]). In Feb02, A differed from $\mathrm{C}$ and $\mathrm{F}$ exclosures (C vs F: pseudo- $F_{1,23}=3.44, p=0.02 ; C$ vs A: pseudo$\mathrm{F}_{2,38}=11.10, p=0.001 ; \mathrm{F}$ vs A: pseudo- $F_{2,38}=4.47, p$ $=0.003$ ). In Jun02, $\mathrm{C}$ differed from $\mathrm{A}$ and $\mathrm{F}$ exclosures (C vs F: pseudo- $F_{1,23}=6.64, p=0.003 ; C$ vs $\mathrm{A}$ : pseudo- $F_{2,38}=7.89, p=0.001 ; \mathrm{F}$ vs A: pseudo- $F_{2,38}=$ $0.76, p=0.5)$.

NMDS plots for each sampling date (Fig. 4A-H) reveal subtle differences. After treatment in the Oct01 (Fig. 4D), Feb02 (Fig. 4F), and Jun02 (Fig. 4H) experimental periods, $\mathrm{C}$ points were mostly on the left side or much closer to 0 in the first component than $\mathrm{A}$ or $\mathrm{F}$ points.

Total sample dry mass was analyzed as a measure of standing crop of benthos and potential invertebrate food for birds. Percent reduction in total dry mass in $\mathrm{C}$ relative to $\mathrm{A}$ exclosures ranged from 28 to $74 \%$ across the 4 periods, and the reduction in $C$ relative to $\mathrm{F}$ exclosures ranged from 9 to $52 \%$. For both $\mathrm{A}$ and F exclosures, Jul01 was the only period with \% 

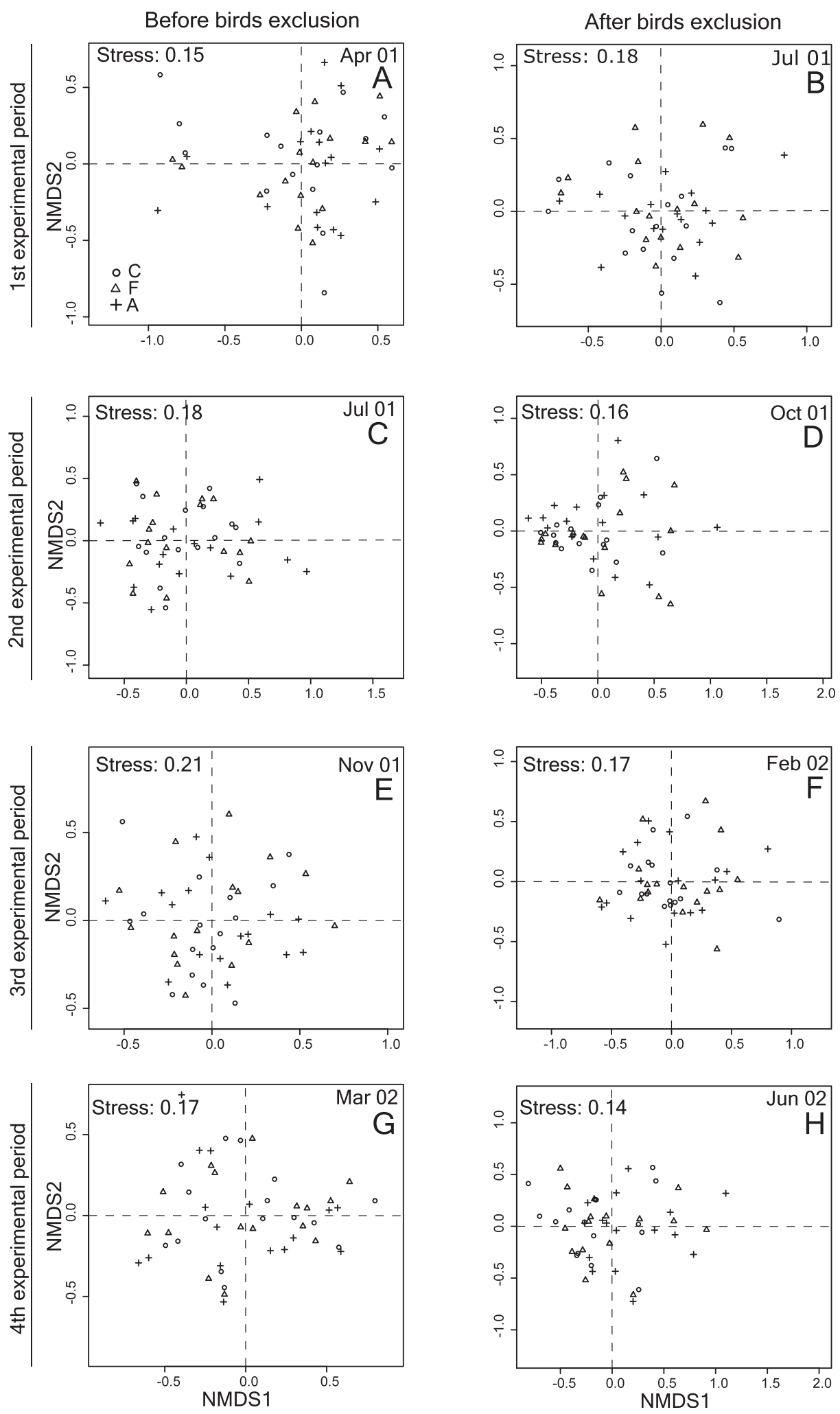

FIG. 4. Nonmetric multidimensional scaling plots for initial (A, C, E, G) and final (B, D, F, H) invertebrate community structure based on Bray-Curtis dissimilarities of $\sqrt{ }(x)$-transformed abundances in the summer $(A, B)$, autumn $(C, D)$, winter $(E$, F), and spring $(\mathrm{G}, \mathrm{H})$ sampling periods. 
reduction $<45 \%$. Exclosure treatment significantly affected dry mass in Oct01, Feb02, and Jun02 (Table 1, Fig. 5A), with the highest mass in $\mathrm{A}$ and lowest in $\mathrm{C}$ exclosures. All pairwise differences between $\mathrm{C}$ and $\mathrm{A}$ and $\mathrm{F}$ exclosures were significant, and in Feb02, $\mathrm{F}$ differed from A exclosures.

Exclosure treatment affected taxon richness in Feb02 and Jun02 (Fig. 5B). In Feb02 and Jun02, 15 and $25 \%$ fewer taxa, respectively, were found in $C$ than A exclosures (Fig. 5B). Taxon richness was significantly higher in $\mathrm{A}$ than in $\mathrm{C}$ exclosures in both periods (Table 1, Fig. 5B).

\section{Invertebratecounts}

We analyzed counts only for experimental periods in which treatment had major effects on community composition (Oct01, Feb02, and Jun02) and only for the 6 most-abundant groups (chironomid larvae, polychaetes, gastropods, amphipods, ostracods, and isopods; Fig. 5A-H). In Table 1, we present results for groups with a net significant effect of treatment and no problems in the distribution of residuals. Combined, the 6 groups analyzed represented $99 \%$ of the total number of invertebrates and 91 to $99 \%$ of the total dry mass for the 4 periods. Hence, 4 groups (polychaetes, chironomids, gastropods, and ostracods) drove the general effect of bird exclusion on community composition. Numbers of chironomids were higher in $\mathrm{A}$ than $\mathrm{C}$ exclosures across all periods, in $\mathrm{A}$ than $\mathrm{F}$ exclosures in Oct01 and Feb02, and in $\mathrm{F}$ than $C$ exclosures in Jun02 (Table 1, Fig. 5C). Numbers of polychaetes were higher in $A$ than $C$ exclosures in Oct01, Feb02, and Jul02 and in F than $\mathrm{C}$ exclosures in Oct01 and Feb02 (Fig. 5D). In Oct01, numbers of the gastropodP.antipodarum were higher in $\mathrm{A}$ than $\mathrm{C}$ and $\mathrm{F}$ exclosures (Fig. 5E). In Jun02, numbers of the ostracodC.torosa were higher in $\mathrm{F}$ and A exclosures than $C$ exclosures (Table 1, Fig. 5F).

\section{Discussion}

Our study provides some of the strongest evidence to date that flamingos and other waterbirds (essentially ducks and coots) have a notable influence on benthic invertebrate abundance and community structure in shallow lakes (sensu Scheffer 1998) throughout the annual cycle, and not just at times of peak migratory concentrations. In their meta-analysis, Marklund et al. (2002) found a strong correlation between reduction of invertebrates and waterfowl density, but the studies included were mainly of diving ducks feeding on bivalves. Furthermore, at densities of waterfowl as low as ours, they found no evidence of effects on benthic macroinvertebrates. The strength of the effects we recorded is even more significant bearing in mind the high density of fish in the study area. The fish species present are likely to compete with waterbirds for benthic food (Cardona et al. 2001, Richardson et al. 1990), and compensatory predation by fish may even have led us to underestimate the influence of birds on benthos (Batzer et al. 2000, Marklund et al. 2002).

The great majority of previous work investigating the influence of waterbirds on benthic invertebrates was focused on the influence of seasonal concentrations of shorebirds in tidal mudflats (Quammen 1984, Botto et al. 1998, Hamilton et al. 2006, Mendoça et al. 2007, Rosa et al. 2008) and other soft sediments (Székely and Bamberger 1992, Sánchez et al. 2006) during migration or winter. Many of these investigators found significant effects of shorebirds, but others have suggested that exclusion of birds has no effect because of compensation by other predators, such as other invertebrates (Marsh 1986, Smith et al. 1986). Ashley et al. (2000) found no influence of waterfowl on the abundance of dipteran larvae, and Marklund et al. (2002) found no negative effects of waterfowl on total macroinvertebrate abundance and biomass (including nekton and benthos). Others have shown that herbivorous waterfowl reduce the abundance of epiphytic and benthic invertebrates at times of the year when waterfowl density peaks (Bortolus et al. 1998, Marklund and Sandsten 2002, Sherfy and Kirkpatrick 2003).

We found strong evidence that waterbirds influence the benthic invertebrate community. Only 3 mo after the application of waterbird exclusion treatments, invertebrate populations increased notably in 3 of 4 experimental periods. In Oct01 and Jun02, we did not find a difference between $\mathrm{F}$ and $\mathrm{A}$ exclosures, a result underlining the importance of Greater Flamingo in such a habitat. On the other hand, in Feb02 when waterfowl were at peak abundance and flamingos were less abundant, ducks and coots shaped the benthic community. The lack of a similar outcome in Jul01 for any of the community metrics (multivariate analysis, richness, and total dry mass), might be partially explained by the fact that the experiment only lasted for $2 \mathrm{mo}$ in 2 of the 8 ponds used. Moreover, this period is the time of lowest waterbird density (Fig. 3A).

The magnitude of the effects changed throughout the annual cycle with changes in the natural abundance of waterbirds and invertebrates. Our results address seasonal changes because our experimental design excluded birds in 4 distinct periods across a whole year. To leave the experimental exclosures in one place without moving them for the whole year 


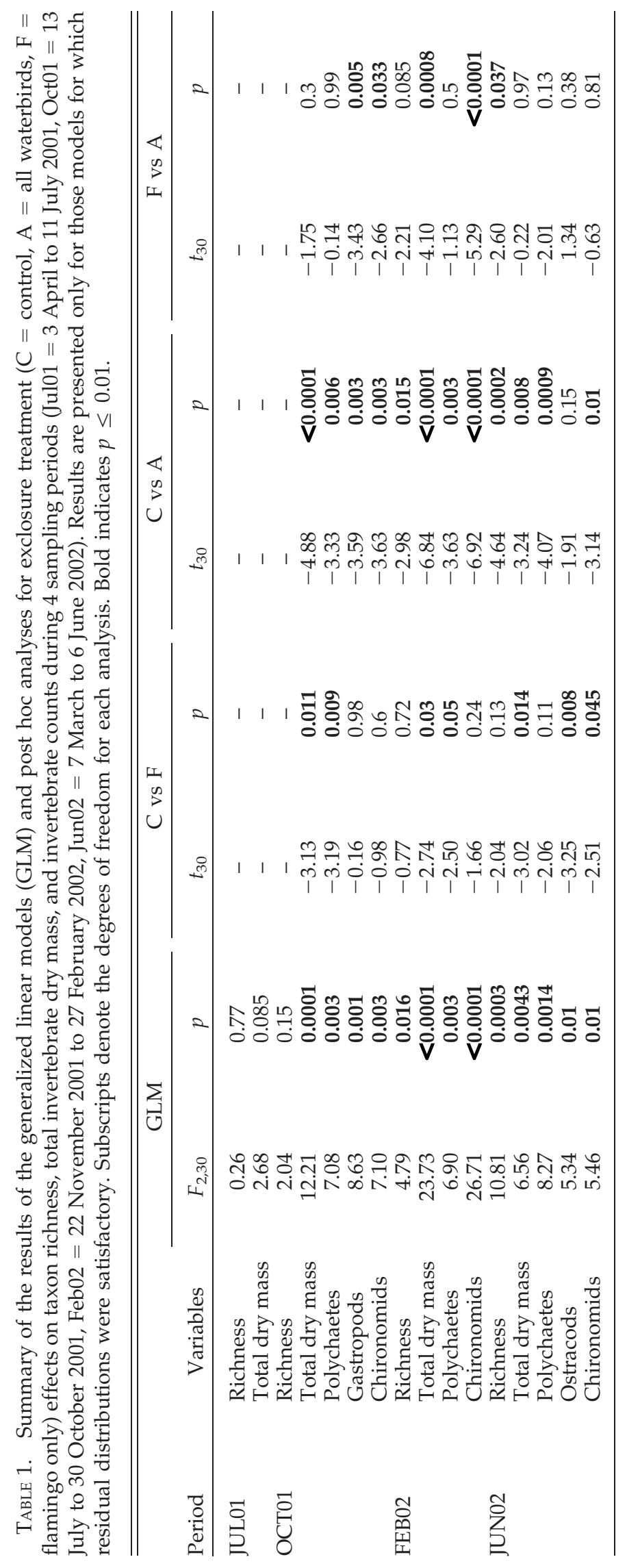



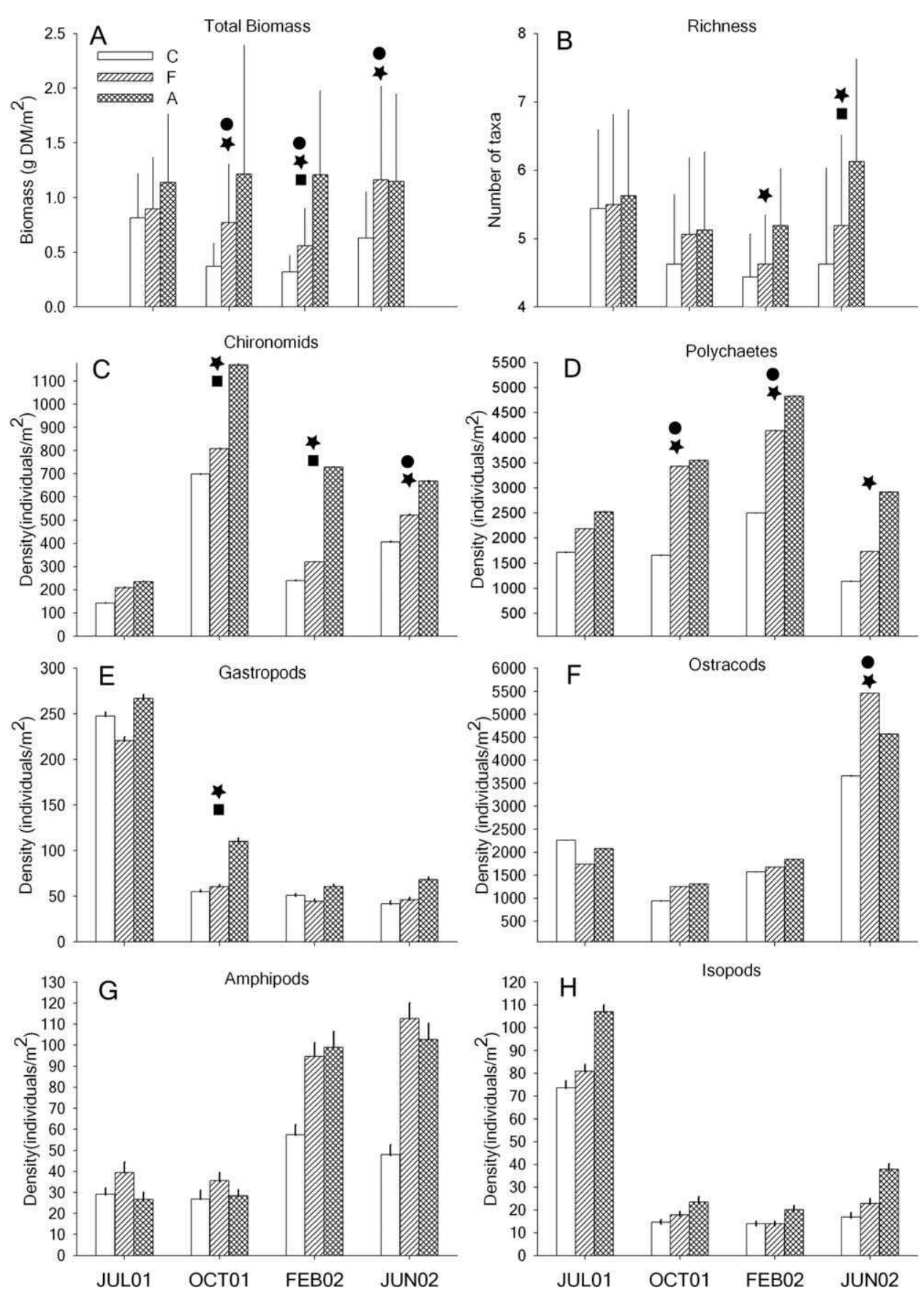

FIG. 5. Arithmetic mean (+1 SE) of total invertebrate dry mass (DM) (A) and taxon richness (B) and geometric mean (+1 SE) of invertebrate density for chironomids (C), polychaetes (D), gastropods (E), ostracods (F), amphipods (G), and isopods (H) for the 4 experimental periods (Jul01 = 3 April to 11 July 2001, Oct01 = 13 July to 30 October 2001, Feb02 = 22 November 2001 to 27 February 2002, Jun02 = 7 March to 6 June 2002). A circle above a group of bars indicates a significant difference between control (C) and flamingo (F) exclosures, a star indicates a significant difference between $\mathrm{C}$ and all waterbird (A) exclosures, and a square indicates a significant difference between $\mathrm{F}$ and A exclosures.

might have produced an effect of the accumulation of invertebrate numbers caused by absence of avian predation and reproduction of invertebrates not predated in the previous season. Furthermore, other indirect effects might arise during such long-term exclusions (see below).

Taxonomic richness was up to $25 \%$ lower in $\mathrm{C}$ than in A exclosures in Feb02 and Jun02. These differences 
may be partially explained by the reduction of macrophytes by waterfowl. Total community dry mass was significantly increased in Oct01, Feb02, and Jun02 by excluding flamingos and in Feb02 by excluding all waterbirds. In these cases, biomass in $\mathrm{C}$ exclosures was reduced by $\sim 1 / 2$ of total biomass compared to $\mathrm{F}$ exclosures and by $1 / 2$ to $3 / 4$ compared to A exclosures. The greatest difference between the $\mathrm{A}$ and $\mathrm{F}$ exclosure treatments occurred in Feb02 when waterfowl numbers peaked and flamingo numbers declined because of winter migration. It is striking that just 1 species, the Greater Flamingo, was responsible for $\sim 1 / 2$ of total biomass reduction. In similar exclosure studies, Hamilton et al. (1994) showed a reduction of $57 \%$ in zebra musselDreissena polymorpha biomass from eider predation, and Sánchez et al. (2006) found a reduction of 36 to $49 \%$ in chironomid biomass from predation by shorebirds. In the most extreme case, Werner et al. (2005) found that exclosures increased zebra mussel biomass $>90 \%$.

Bird exclusion significantly affected abundances of polychaetes, chironomids, gastropods, and ostracods. The largest effects were during Oct01 and Feb02 (post-breeding and wintering periods) when concentrations of birds were highest (Fig. 3A). For example, in both of these periods, $\mathrm{F}$ and $\mathrm{A}$ exclosures had $>2 \times$ as many polychaetes as $C$ exclosures (Fig. 5D). Polychaetes and chironomids were the most abundant benthic groups numerically and in terms of biomass and constituted, for example, up to $70 \%$ of total biomass in Oct01. Only in Jun02, when ostracods peaked in abundance (Fig. 5F), did the biomass of chironomids and polychaetes make up $<50 \%$ of total biomass. Exclusion of flamingos and all birds had similar effects on polychaete numbers, especially in Oct01 and Feb02 (Table 1, Fig. 5D). These results suggest that flamingos contributed greatly to the effect of exclusion of all waterbirds. In tidal lagoons in Namibia, exclusion of flamingos increased the abundance of 3 polychaetes, but the largest species Diopatra neapolitana was more abundant in controls than in exclosures (Glassom and Branch 1997a). We also found a highly significant reduction of chironomid numbers by all waterbirds for the same 3 periods. Chironomid larvae are very important in waterfowl diets (Krapu and Reinecke 1992, Kear 2005). The relatively greater effect of flamingos on polychaetes than on chironomids may be partly because chironomids are epifaunal and polychaetes infaunal (Kornijów and Moss 1998, Angradi et al. 2001), whereas flamingos feed deeper in the sediments than ducks and coot via trampling. This apparent trophic segregation might relax competition for food between flamingos and ducks. Benthic chironomids also may be more negatively affected than polychaetes by the loss of macrophytes via waterfowl herbivory (Marklund and Sandsten 2002, Sherfy and Kirkpatrick 2003, but see Wrubleski 1989). Nevertheless, flamingos reduced the abundance of benthic chironomids in temporary marshes without having a measurable effect on macrophytes (Rodríguez-Pérez et al. 2007).

Significant effects of waterbirds on gastropods and ostracods were recorded for at least 1 period. Greater Flamingos consume polychaetes, ostracods, chironomid larvae, and other benthic organisms (Glassom and Branch 1997a, Johnson 1997, Rodríguez-Pérez and Green 2006). In our study area, analysis of the gut contents of ducks and coot confirmed that they consume chironomid larvae, isopods, amphipods, polychaetes, ostracods, and gastropods (Green and Sánchez 2003, HR-P and AJG, unpublished data). However, our results also are likely to reflect the bioturbation (sensu Meysman et al. 2006) effects of waterbirds and the effects of exclosure on submerged macrophytes, which have a major structuring role on invertebrate communities (reviewed by Jeppesen et al. 1998).

Bioturbation can have significant deleterious effects on suspension feeders and tube builders, such as polychaetes and chironomid larvae (Wilson 1991). Crabs, fish, shorebirds, and flamingos can cause significant disturbance to soft-sediment communities (Quammen 1984, Thrush et al. 1994, Glassom and Branch 1997a, b). In our study area, flamingos form craters while feeding (Fig. 1) and uproot the submerged macrophyte Ruppia maritima (RodríguezPérez and Green 2006). Waterfowl also are likely to cause disturbance to sediments while grazing on $R$. maritima and feeding on benthic invertebrates.

The Greater Flamingo has been shown by exclosure experiments to influence macro- and meiofauna in intertidal areas (Glassom and Branch 1997a, b), whereas the Andean Flamingo (Phoenicoparrus andinus) also profoundly affects microbenthos (Hurlbert and Chang 1983). The Greater Flamingo can be considered a bioturbator because it alters the sediment topography (Fig. 1; Kvitek et al. 1992, Thrush et al. 1994) and modifies physicochemical sediment features, such as redox potential and organic content (Glassom and Branch 1997b). Such sediment features are closely linked to the densities of benthos (Marinelli and Woodin 2002), and bioturbation by waterbirds can even affect biogeochemical cycles (Lohrer et al. 2004, Bodelier et al. 2006).

Numbers of Greater Flamingos have been increasing continually in the Mediterranean region since the 1960s (Wetlands International 2006, Rendón et al. 2008) because of management measures focused on 
this bird, which is particularly attractive to humans. The species is strictly protected, and artificial nesting islands are carefully maintained (Martos and Johnson 1996). Extensive loss of coastal wetlands ( $50 \%)$ over the same time period has led to a further increase in the density of flamingos in the remaining wetlands. The Greater Flamingo now represents up to $80 \%$ of annual waterbird biomass in coastal Andalusian wetlands (Consejería de Medio Ambiente, unpublished data), and few other waterbird species have been increasing at such a rate (Rendón et al. 2008). The new dominance of this species and our results indicate that the Greater Flamingo plays an important functional role in Mediterranean marshes. Other investigators have shown how it remobilizes sediments and nutrients into the water column and leads to loss of submersed macrophytes (Comín et al. 1997, Rodríguez-Pérez et al. 2006). Managers should pay attention to its potential role in competition for food or space with other waterbirds and its potential role in shifting aquatic systems from a more biodiverse clearwater phase dominated by submersed vegetation to a turbid phase dominated by phytoplankton. Encouraging flamingos may help to bring visitors to a wetland, but might have negative consequences for habitat conservation in some circumstances.

Experiments like ours in which predators are excluded often have indirect or unexpected effects, in which exclusion decreases the density of some species in a manner that cannot be explained directly via predation by the excluded predators (reviewed by Sih et al. 1985 and Wootton 2002). Such results have been explained either by compensatory predation (Kneib 1988, Thrush et al. 1994, Hamilton 2000) or by interspecific or adult-larval intraspecific competition (Peterson 1979, Wilson 1991, Thrush 1999). Adultlarval competition is thought to be important in softsediment communities and typically leads to a reduction in density but increase in size in exclosures (Woodin 1976, Peterson 1979, Wilson 1991, Olafsson et al. 1994, Rodríguez-Pérez et al. 2007). However, we did not find evidence for any taxa of a decrease in abundance in exclosures. Thus, our results suggest that competition has relatively little influence on community structure in our study area and support the prediction that indirect effects are more common when predation intensity is low (Sih et al. 1985). Nevertheless, we cannot rule out the possibility that indirect effects would have been manifested if we had maintained exclosures for a longer time (see Hamilton 2000).

The strength of exclosure effects in different periods appears to depend partly on fluctuations in abundance of waterbirds. However, exclosure effects also are likely to depend critically on how the timing of the experiment relates to growth rates and other aspects of invertebrate life cycles (Mitchell and Wass 1996) and on diet switches by waterbirds in relation to their nutritional needs and changes in the size distribution of available prey (Krapu and Reinecke 1992, Kear 2005). Invertebrate growth and reproductive rates are likely to be much lower during the cooler winter months, such that a given amount of avian predation will have greater effects at that time. Such effects may explain the general lack of exclosure effects in Jul01, when warm temperatures and rapid reproduction may have led invertebrates to escape demographic control by predation.

In conclusion, we have found evidence for strong top-down control of benthos by waterbirds in shallow lakes. This strong functional role of waterbirds in aquatic ecosystems has been largely overlooked, in contrast with the extensive literature on such a role for fish (Green and Figuerola 2005). The nature of this structuring role is complex, with major differences between waterbird groups and seasons, which in turn, interact with each other. None of these effects are entirely consistent among different benthic taxa. Future studies are required to understand the extent to which this structuring role of birds is consistent among systems. For example, how does it vary with hydroperiod, and is it maintained in the temporary systems that abound in semi-arid and arid environments? To what extent is the observed role for birds dependent on predation and to what extent on bioturbation and herbivory? Future research also should be designed to test whether indirect effects mediated via competition or compensatory predation would become apparent in long-term exclosure experiments.

\section{Acknowledgements}

Maria del Mar Delgado provided invaluable assistance processing samples. We also thank Esther Macarro for field assistance. Arnthór Gardarsson, Andrés Millán, Ángel Baltanás, José Manuel Guerra, and Juan Carlos Pérez assisted with taxonomic identifications. Pesquerías Isla Mayor S. A. and the Department of Environment (Consejería de Medio Ambiente) of the Andalusian Autonomous Government gave us permission to work in Veta la Palma. This work was funded by the Consejería de Medio Ambiente. Héctor Rodríguez-Pérez had a PhD grant from the CSIC-I3P programme funded by the European Social Fund. Stuart Hurlbert, Diana Hamilton, and 2 anonymous referees made insightful comments that allowed us to improve the manuscript greatly. 


\section{Literature Cited}

Almaraz, P., A. J. Green, E. Aguilera, M. A. Rendón, And J. Bustamante. 2012. Estimating partial observability and nonlinear climate effects on stochastic community dynamics of migratory waterfowl. Journal of Animal Ecology (in press). doi:10.1111/j.1365-2656.2012.01972.x

Anderson, M. J. 2001. A new method for non-parametric multivariate analysis of variance. Austral Ecology 26: 32-46.

Angradi, T. R., S. M. Hagan, and K. W. Able. 2001. Vegetation type and the intertidal macroinvertebrate fauna of a brackish marsh:Phragmites vs.Spartina . Wetlands 21:75-92.

Argano, R. 1979. Guide per il riconoscimento delle specie animali delle acque interne italiane 5. Isopodi. Consiglio Nazionale delle Ricerche, Roma, Italy.

Ashley, M. C., J. A. Robinson, L. W. Oring, and G. A. Vinyard. 2000. Dipteran standing stock biomass and effects of aquatic bird predation at a constructed wetland. Wetlands 20:84-90.

Askew, R. R. 1988. The dragonflies of Europe. Harley Books, Colchester, UK.

Batzer, D. P., C. R. Pusateri, and R. Vetter. 2000. Impact of fish predation on marsh invertebrates: direct and indirect effects. Wetlands 20:307-312.

Berlow, E. L. 1997. From canalisation to contingency: historical effects in a successional rocky intertidal community. Ecological Monographs 67:435-460.

Bodelier, P. L. E., M. Stomp, L. Santamaría, M. Klaassen, and H. J. LaAnbroek. 2006. Animal-plant-microbe interactions: direct and indirect effects of swan foraging behaviour modulate methane cycling in temperate shallow wetlands. Oecologia (Berlin) 149:233-244.

Bortolus, A., O. O. Iribarne, And M. M. Martinez. 1998. Relationship between waterfowl and the seagrass Ruppia maritima in a southwestern Atlantic coastal lagoon. Estuaries 21:710-717.

Botto, F., O. O. Iribarne, M. M. Martinez, K. Delhey, and M. CARRETE. 1998. The effect of migratory shorebirds on the benthic species of three southwestern Atlantic Argentinean estuaries. Estuaries 21:700-709.

Cardona, L., P. Royo, And X. Torras. 2001. Effects of leaping grey mulletLizasaliens (Osteichthyes, Mugilidae) in the macrophyte beds of oligohaline Mediterranean coastal lagoons. Hydrobiologia 462:233-240.

Castello, J. 1986. Contribución al conocimiento biológico de los crustáceos del litoral Catalano-Balear. PhD Thesis, Barcelona University, Barcelona, Spain.

Castroviejo, J. 1993. Mapa del Parque Nacional de Doñana. Consejo Superior de Investigaciones Científicas y Agencia de Medio Ambiente de la Junta de Andalucía, Madrid, Spain. (Available from: Estacion Biológica de Doñana- CSIC. C/Américo Vespucio, s/n. E-41092 Sevilla, Spain.)

Comín, F. A., J. A. Herrera-Silveira, and M. Martín. 1997. Flamingo footsteps enhance nutrient release from the sediment to the water column. Pages 211-227 in S. Faragó and J. J. Kerekes (editors). Limnology and waterfowl. Monitoring, modelling and management. Publication 43. Wetlands International, Sopron, Hungary.

Crawley, M. J. 1993. GLIM for ecologists. Blackwell Science, London, UK.

del Hoyo, J., A. Elliot, and J. Sargatal (editors). 1992. Handbook of the birds of the world. Lynx Editions, Barcelona, Spain.

DufFY, J. E. 2002. Biodiversity and ecosystem function: the consumer connection. Oikos 99:201-219.

Fauvel, P. 1923. Faune de France 5. Polychètes Errantes. Le Chavalier, Paris, France.

Fauvel, P. 1927. Faune de France 16. Polychètes Sédentaires. Le Chevalier, Paris, France.

Frisch, D., H. Rodríguez-Pérez, AND A. J. GreEn. 2006. Invasion of artificial ponds in Doñana Natural Park, southwest Spain, by an exotic estuarine copepod. Aquatic Conservation: Marine and Freshwater Ecosystems 16:483-492.

Gayet, G., M. Guillemain, H. Fritz, M. François, C. Begnis, A. Costiou, G. Body, L. Curtet, and J. Broyer. 2011. Do mute swan (Cygnus olor) grazing, swan residence and fishpond nutrient availability interactively control macrophyte communities? Aquatic Botany 95:110-116.

Ghetti, P. F., And K. McKenzIe. 1981. Guide per il riconoscimento delle specie animali delle acque interne italiane 11. Ostracodi. Consiglio Nazionale delle Ricerche, Roma, Italy.

GLASSOM, D., AND G. M. BRANCH. 1997a. Impact of predation by greater flamingosPhoenicopterus ruber on the macrofauna of two southern African lagoons. Marine Ecology Progress Series 149:1-12.

Glassom, D., AND G. M. BRANCH. 1997b. Impact of predation by Greater Flamingos Phoenicopterus ruber on the meiofauna, microflora, and sediment properties of two southern African lagoons. Marine Ecology Progress Series 150:1-10.

GrEEN, A. J. 1998. Comparative feeding behaviour and niche organization in a Mediterranean duck community. Canadian Journal of Zoology - Revue Canadienne De Zoologie 76:500-507.

Green, A. J., And J. Figuerola. 2005. Recent advances in the study of long-distance dispersal of aquatic invertebrates via birds. Diversity and Distributions 11:289-296.

GreEn, A. J., AND M. I. SÁNChez. 2003. Spatial and temporal variation in the diet of Marbled Teal Marmaronetta angustirostris in the western Mediterranean. Bird Study 50:153-160.

Hamilton, D. J. 2000. Direct and indirect effects of predation by Common Eiders and abiotic disturbance in an intertidal community. Ecological Monographs 70:21-43.

Hamilton, D. J., C. D. Ankney, And V. Bailey. 1994. Predation of zebra mussels by diving ducks: an exclosure study. Ecology 75:521-531.

Hamilton, D. J., A. W. Diamond, And P. G. Wells. 2006. Shorebirds, snails, and the amphipod (Corophium volutator) in the upper Bay of Fundy: top-down vs. bottom-up factors, and the influence of compensatory 
interactions on mudflats ecology. Hydrobiologia 567: 285-306.

Holthe, T. 1986. Polychaeta Terebellomorpha. Marine Invertebrates of Scandinavia 7. Norwegian University Press, Oslo, Norway.

Hurlbert, S. H. 1984. Pseudoreplication and the design of ecological field experiments. Ecological Monographs 54: 187-211.

Hurlbert, S. H., AND C. C. Y. Chang. 1983. Ornitholimnology: effects of grazing by the Andean Flamingo (Phoenicoparrus andinus). Proceedings of the National Academy of Sciences of the United States of America: Biological Sciences 80:4766-4769.

JANSSON, A. 1986. The corixidae (Heteroptera) of Europe and some adjacent regions. Acta Entomologica Fennica 47.

Jeppesen, E., M. SøndergaArd, M. SøndergaArd, And K. E. CHRISTOFFERSEN. 1998. The structuring role of submerged macrophytes in lakes. Springer-Verlag, New York.

Johnson, A. R. 1997. Long-term studies and conservation of Greater Flamingos in the Camargue and Mediterranean. Colonial Waterbirds 20:306-315.

KeAR, J. (EDITOR). 2005. Ducks, geese and swans. Oxford University Press, Oxford, UK.

Kloskowski, J., A. J. Green, M. Polak, J. Bustamante, and J. Krogulec. 2009. Complementary use of natural and artificial wetlands by waterbirds wintering in Doñana, south-west Spain. Aquatic Conservation: Marine and Freshwater Ecosystems 19:815-826.

KNEIB, R. T. 1988. Testing for indirect effects of predation in an intertidal soft-bottom community. Ecology 69: 1795-1805.

Kornijów, R., And B. Moss. 1998. Vertical distribution of inbenthos in relation to fish and floating-leaved macrophyte population. Pages 227-232 in E. Jeppesen, M. Søndergaard, M. Søndergaard, and K. E. Christoffersen (editors). The structuring role of submerged macrophytes in lakes. Springer-Verlag, New York.

KRAPU, G. L., AND K. J. ReINECKE. 1992. Foraging ecology and nutrition. Pages 1-29in B. D. J. Batt, A. D. Afton, M. G. Anderson, C. D. Ankney, D. H. Johnson, J. A. Kadlec, and G. L. Krapu (editors). Ecology and management of breeding waterfowl. University of Minnesota Press, Minneapolis, Minnesota.

Kvitek, R. G., J. S. Oliver, A. R. Degange, and B. S. Anderson. 1992. Changes in Alaskan soft-bottom prey communities along a gradient in sea otter predation. Ecology 73: 413-428.

Lohrer, A. M., S. F. Thrush, And M. M. Gibbs. 2004. Bioturbators enhance ecosystem function through complex biogeochemical interactions. Nature 431:1092-1095.

Lubchenco, J., And B. A. Menge. 1978. Community development and persistence in low rocky intertidal zone. Ecological Monographs 59:67-94.

Marinelli, R. L., AND S. A. Woodin. 2002. Experimental evidence for linkages between infaunal recruitment, disturbance, and sediment surface chemistry. Limnology and Oceanography 47:221-229.

Marklund, O., AND H. SAndsten. 2002. Reduction of benthic macroinvertebrates due to waterfowl foraging on submerged vegetation during autumn migration. Aquatic Ecology 36:541-547.

Marklund, O., H. Sandsten, L.-A. Hansson, and I. Blindow. 2002. Effects of waterfowl and fish on submerged vegetation and macroinvertebrates. Freshwater Biology 47:2049-2059.

Marsh, C. P. 1986. Rocky intertidal community organization: the impact of avian predators on mussel recruitment. Ecology 67:771-786.

Martos, M. R., AND A. R. Johnson. 1996. Management of nesting sites for Greater Flamingos. Colonial Waterbirds 19:167-183.

McCullagh, P., And J. A. Nelder. 1989. Generalized linear models. Chapman and Hall, Boca Raton, Florida.

MendoçA, V. M., D. G. Raffaelli, and P. R. BoYle. 2007. Interactions between shorebirds and benthic invertebrates at Culbin Sands Lagoon, NE Scotland: effects of avian predation on their prey community density and structure. Scientia Marina 71:579-591.

Menge, B. A., E. L. Berlow, C. A. Blanchette, S. A. Navarrete, AND S. B. YamadA. 1994. The keystone species concept: variation in interaction strength in a rocky intertidal habitat. Ecological Monographs 64:249-286.

Menge, B. A., And V. Sutherland. 1987. Community regulation: variation in disturbance, competition, and predation in relation to environmental stress and recruitment. American Naturalist 130:730-757.

Meysman, F. J. R., J. J. Middelburg, and C. H. R. Heir. 2006. Bioturbation: a fresh look at Darwin's last idea. Trends in Ecology and Evolution 21:688-695.

Mitchell, J. S., R. C. Bailey, and R. W. Knapton. 2000. Effects of predation by fish and wintering ducks on dreissenid mussels at Nanticoke, Lake Erie. Ecoscience 7:398-409.

Mitchell, S. F., AND M. R. Perrow. 1998. Interaction between grazing birds and macrophytes. Pages 175-196 in E. Jeppesen, M. Søndergaard, M. Søndergaard, and K. E. Christoffersen (editors). The structuring role of submerged macrophytes in lakes. Springer-Verlag, New York.

Mitchell, S. F., AND R. T. WAss. 1996. Quantifying herbivory: grazing consumption and interaction strength. Oikos 76: 573-576.

OKSANEN, J. 2011. vegan: community ecology package. Version 1.17-6. R Project for Statistical Computing, Vienna, Austria. (Available from: http://CRAN.R-project.org/ package $=$ vegan $)$

Olafsson, E. B., C. H. Peterson, and W. G. Ambrose. 1994. Does recruitment limitation structure populations and communities of macro-invertebrates in marine soft sediments: the relative significance of pre-settlement and post-settlement processes. Oceanography and Marine Biology 32:65-109.

Ortiz, M., AND A. Jimeno. 2001. Guía ilustrada para la identificación de las familias y los géneros de los anfípodos del suborden gammaridea de la península Ibérica. Graellsia 57(2):3-93.

PAINE, R. T. 1966. Food web complexity and species diversity. American Naturalist 100:65-75. 
PAINE, R. T. 1980. Food webs: linkage, interaction strength, and community infrastructure. Journal of Animal Ecology 49:667-685.

Peterson, C. H. 1979. Predation, competitive exclusion, and diversity in the soft-sediment benthic communities of estuaries and lagoons. Pages 233-264in R. J. Livingstone (editor). Ecological processes in coastal and marine systems. Plenum Press, New York.

PöYsä, H. 1983. Morphology-mediated niche organization in a guild of dabbling ducks. Ornis Scandinavica 14:317-326.

Quammen, M. L. 1984. Predation by shorebirds, fish, and crabs on invertebrates in intertidal mudflats: an experimental test. Ecology 65:529-537.

Rendón, M. A., A. J. Green, E. Aguilera, and P. Almaraz. 2008. Status, distribution and long-term changes in the waterbird community wintering in Doñana, south-west Spain. Biological Conservation 141:1371-1388.

Richardson, W. B., S. A. Wickham, and S. T. Threlkeld. 1990. Foodweb response to the experimental manipulation of a benthivore (Cyprinus carpio), zooplanktivore (Menidia beryllina) and benthic insects. Archiv für Hydrobiologie 119:143-165.

Rodríguez-Pérez, H., M. Florencio, C. Gómez-Rodríguez, A. J. Green, C. Díaz-Paniagua, and L. Serrano. 2009. Monitoring the invasion of the aquatic bug Trichocorixa verticalis verticalis (Hemiptera: Corixidae) in the wetlands of Doñana National Park (SW Spain). Hydrobiologia 634:209-217.

Rodríguez-PÉrez, H., AND A. J. GREen. 2006. Waterbird impacts on widgeongrassRuppiamaritima in a Mediterranean wetland: comparing bird groups and seasonal effects. Oikos 112:525-534.

Rodríguez-Pérez, H., A. J. Green, and J. Figuerola. 2007. Effects of Greater Flamingo Phoenicopterus ruber on macrophytes, chironomids and turbidity in natural marshes in Doñana, SW Spain. Fundamental and Applied Limnology 172:167-175.

Rosa, S., J. P. Granadeiro, C. Vinagre, S. França, H. N. Cabral, and J. M. Palmeirim. 2008. Impact of predation on the polychaete Hediste diversicolor in estuarine intertidal flats. Estuarine, Coastal and Shelf Science 78: 655-664.

Roughgarden, J., J. Diamond. 1986. Overview: the role of species interactions in community ecology. Pages 333-343 in J. Diamond, AND T. J. Case. 1986. Community ecology. Harper and Row, New York.

Ruffo, S. 1982. The Amphipoda of the Mediterranean. Mémoires de l'Institut Océanographique 13. Fondation Albert I Prince de Monaco, Monaco, Monaco.

SÁnchez, M. I., A. J. GreEn, AND R. AlejANDRe. 2006. Shorebird predation affects abundance and size distribution of benthic chironomids in saltpans: an exclosure experiment. Journal of the North American Benthological Society 25:9-18.

SCHEFFER, M. 1998. Ecology of shallow lakes. Kluwer Academic Publisher, Dordrecht, The Netherlands.

Sherfy, M. H., AND R. L. KiRKPATRICK. 2003. Invertebrate response to snow goose herbivory on moist-soil vegetation. Wetlands 23:236-249.
Sih, A., P. Crowley, M. McPeek, J. Petranka, and K. Strohmeier. 1985. Predation, competition, and prey communities: a review of field experiments. Annual Review of Ecology and Systematics 16:269-311.

Smith, D., R. G. Hughes, And E. J. Cox. 1996. Predation of epipelic diatoms by the amphipod Corophium volutator and the polychaete Nereis diversicolor. Marine Ecology Progress Series 145:53-61.

Smith, L. M., L. D. Vangilder, R. T. Hoppe, S. J. Morreale, and I. L. BRISBIN. 1986. Effect of diving ducks on benthic food resources during winter in South Carolina, U.S.A. Wildfowl 37:136-141.

SousA, W. P. 1979. Disturbance in marine intertidal boulder fields. The nonequilibrium maintenance of species diversity. Ecology 60:1225-1239.

SzéKely, T., And Z. Bamberger. 1992. Predation of waders (Charadrii) on prey populations: an exclosure experiment. Journal of Animal Ecology 61:447-456.

TACheT, H., P. Richoux, M. Bournaud, AND P. UsseglioPOLATERA. 2003. Invertébrés d'eau douce: systématique, biologie, écologie. CNRS Editions, Paris, France.

Thrush, S. F. 1999. Complex role of predators in structuring soft-sediment macrobenthic communities: implications of changes in spatial scale for experimental studies. Australian Journal of Ecology 24:344-354.

Thrush, S. F., R. D. Pridmore, J. E. Hewitt, and V. J. Cummings. 1994. The importance of predators on a sandflat: interplay between seasonal changes in prey densities and predator effects. Marine Ecology Progress Series 107:211-222.

Vadeboncoeur, Y., M. J. Vander Zanden, And D. M. Lodge. 2002. Putting the lake back together: reintegrating benthic pathways into lake food web models. BioScience 52:44-54.

Verhoeven, J. T. A. 1980. The ecology of Ruppia dominated communities in western Europe. 2. Synecological classification. Structure and dynamics of the macroflora and macrofauna communities. Aquatic Botany 8:1-85.

Weisner, S. E. B., J. A. Strand, and H. SAndsten. 1997. Mechanisms regulating abundance of submerged vegetation in shallow eutrophic lakes. Oecologia (Berlin) 109:592-599.

Werner, S., M. Mörtl, H. G. Bauer, and K. O. Rothhaupt. 2005. Strong impact of wintering waterbirds on zebra mussel (Dreissena polymorpha) populations at Lake Constance, Germany. Freshwater Biology 50:1412-1426.

WetLANDS InTERNATIONAL. 2006. Waterbird population estimates. $4^{\text {th }}$ edition. Wetlands International, Wageningen, The Netherlands.

WiLson, W. H. 1991. Competition and predation in marine soft-sediment communities. Annual Review of Ecology and Systematics 21:221-241.

Woodin, S. A. 1976. Adult-larval interactions in dense infaunal assemblages: patterns of abundance. Journal of Marine Research 34:25-41.

WootTon, J. T. 2002. Indirect effects in complex ecosystems: recent progress and future challenges. Journal of Sea Research 48:157-172. 
Wrubleski, D. A. 1989. The effect of waterfowl feeding on a chironomid (Diptera: Chironomidae) community. Pages 691-696 in R. R. Sharitz and J. W. Gibbons (editors). Freshwater wetlands and wildlife. Office of Scientific and Technical Information, US Department of Energy, Oak Ridge, Tennessee.

Yamamuro, M., N. OKa, And J. Hiratsuka. 1998. Predation by diving ducks on the biofouling mussel Musculista senhousia in a eutrophic estuarine lagoon. Marine Ecology Progress Series 174:101-106.
ZAR, J. H. 1996. Biostatistical analysis. Prentice-Hall International, Upper Saddle River, New Jersey.

Zuur, A. F., E. N. Ieno, N. J. Walker, A. Saveliev, and G. M. SMith. 2009. Mixed effects model and extensions in ecology with R. Springer, Milton Keynes, UK. 